\title{
Sports Manager Training and Leadership Behaviors
}

\author{
Elif Bozyigit ${ }^{1}$ \\ ${ }^{1}$ Faculty of Sport Sciences, Pamukkale University, Denizli, Turkey \\ Correspondence: Elif Bozyigit, Faculty of Sport Sciences, Pamukkale University, Denizli, Turkey. E-mail: \\ ebozyigit@gmail.com
}

Received: February 15, 2019

Accepted: March 14, 2019 Online Published: March 19, 2019

doi:10.5539/jel.v8n2p248

URL: https://doi.org/10.5539/jel.v8n2p248

\begin{abstract}
The aim of this study is to examine the leadership behaviors levels of university students studying in the Sports Management Department. The sample of the research consists of 148 students (male $n=112$, female $n=36$ ) aged between 18 and 28 years. In this study, the Personal Information Form was created in order to learn the characteristics of the participants such as gender, age groups, the status of doing sports as an athlete and the status of volunteering in sports events. The Leader Behavior Description Questionnaire (LBDQ), which was translated into the Turkish Language by Atar and Özbek (2009), was used as a data collection tool. The mean score of the students was 4.142 in the dimension of initiating structure and was 3.760 in the dimension of consideration. According to the results of the analysis, the initiating structure dimension scores differed according to variables of gender, the status of doing sports as an athlete and the status of volunteering in sports events. The consideration dimension scores differed age groups and the status of volunteering in sports events. In addition, it was found that there was a linear and significant relationship between scores of initiating structure and consideration.
\end{abstract}

Keywords: leadership behavior, leadership training, manager training, sports manager, student

\section{Introduction}

Sports management training is given in the sports management departments of universities in Turkey. These departments may take place in the state or foundation universities. When the educational programs of these departments are examined, it is seen that they consist of different curricula. When the curricula of these departments, which have four years of education, are examined, they can be seen that there are many courses related to administration and management. There is also a sports management program with 2 years of Open Education System, for example, Anadolu University (FOE-SM, 2019). When the objectives of these programs are examined, it is seen that there are different objectives varying according to universities (FOE-SM, 2019; PAU-SA, 2019). It can be said that there are very few courses related to leadership in these departments. In fact, there is no course on leadership in the Open Education System.

The educational program of the sports management students examined in this study covers a period of four years (eight terms including fall and spring). The students of this department take various courses related to sport management, including compulsory and elective courses. In addition, some of the courses are theoretical and some courses are also applied in practice (Bozyigit, 2017). According to PAU-IPCC (2019), some of the compulsory and elective courses related to management are as follows: Compulsory courses: management science, public administration, general business, sport management, recreation management, ethics in sport and management, organization management, special topics in sports management. Elective courses: related to management include club structure management and problems, international sports management, contemporary developments in management, crisis management, risk management, total quality management, strategic planning in management, sports officiating and competition management, leadership and sports, group dynamics and leadership, and educational leadership.

As shown in Figure 1, courses related to leadership are in the category of elective courses. Considering that each course is taken once every 4 years, it is possible to say that there are very few courses about leadership. In this case, perhaps, the student may not choose a course related to leadership. However, in the literature, it is stated that the desired manager style in working life is managers who have leadership behaviors and characteristics. Therefore, leadership training is very important for a student who is trained as a manager. 


\section{Courses}

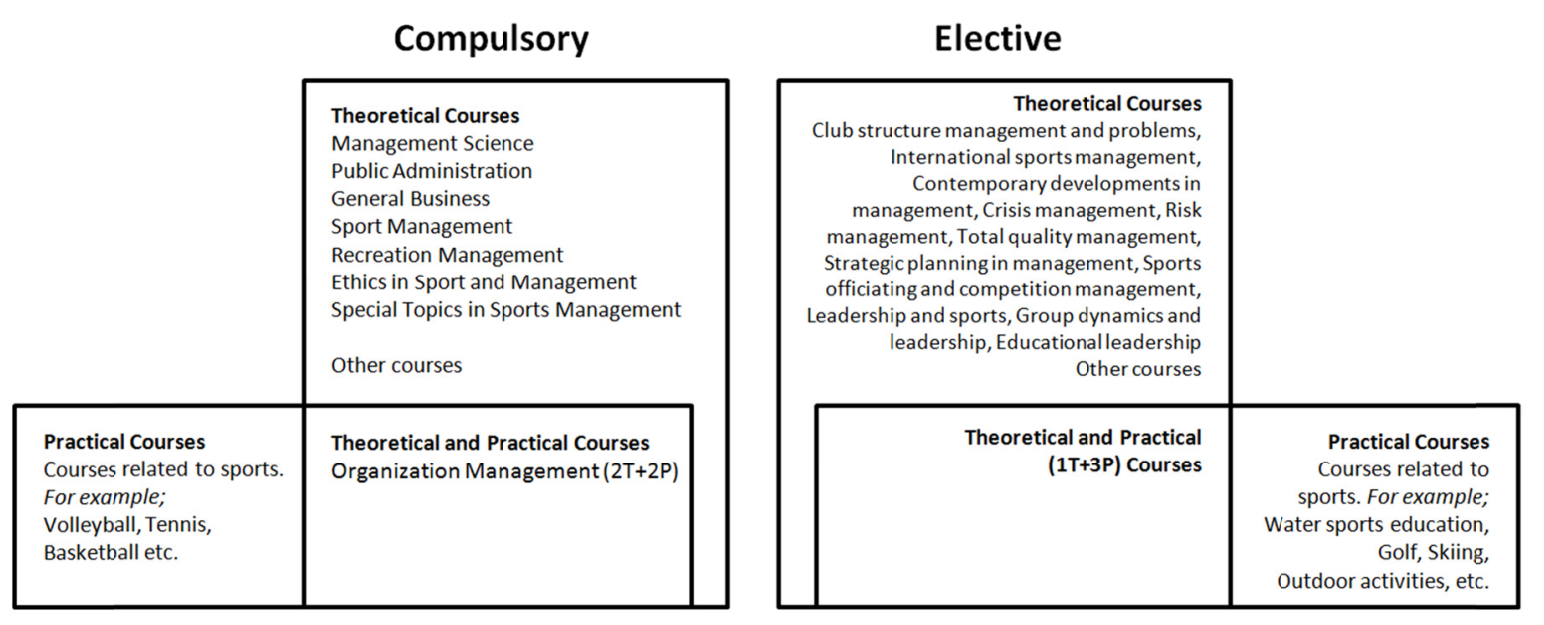

Figure 1. The model of sports manager training in Turkey

The word "behavior" is defined as "the way in which one acts or conducts oneself, especially towards others" or, "the way in which an animal or person behaves in response to a particular situation or stimulus" (Oxford Dictionaries, 2019). Human behavior may include movement, attitude, and style, observable, verbal or nonverbal. Therefore, the behaviors of a leader are also actions taken into account by followers. Behavioral theories claim that a person can become a leader through the training process. For that reason, leadership training should not only include theoretical knowledge, but also practical training.

The concept of leadership can be dated to the early times of humanity. According to Şişman (2002), the concept has been used in the academic sense since the first half of the 19th century. The group is one of the most basic concepts of sociology (Öztürk, 1998) and group leadership for groups to work, come together and organize requires some features such as authority, role, communication and sociometric structure (Eren, 2010). In general, it is stated in the literature that people will always need leaders because of their being a social entity (Bayrak, 1997), that leadership will not lose its importance (Parlak, 2016), in the future, that leaders will need more intensity in organizations (Tengilimoğlu, 2005), and that today's organizations will need effective leaders who understand the complexity of the rapidly changing global environment (Nanjundeswaraswamy \& Swamy, 2014). Leadership for reasons like these has always been a concept that has been constantly developed by researchers since its emergence or noticed.

Most of the definitions given in the Turkish literature on leadership include leading a group, motivating employees to make their work more efficient, gathering a group of people for a specific purpose, detecting problems and showing solution options to members (Doğan, 2007; Eren, 2010). In the simplest terms, we can say that leadership is the ability to influence, motivate and guide other members of the organization in order to achieve targeted goals. In the literature, there are a lot of studies and phrases about leading behaviors such as leadership styles, leadership acts, leadership role, and leadership approaches.

In the leadership process, there are leader and followers. The concept of follower describes a passive behavior and dependence on the leader. However, leadership approaches focus on a multifaceted interaction between the leader and the followers (Çelik, 2005). It can be said that the leader behaviors have many effects on the followers. Therefore, it is thought that behaviors of individuals who will be managers are important.

When the leadership theories are examined, it is seen that it develops in four basic stages. These theories are Trait Theory, Behavioral Theories, Contingency Theories, Modern/Contemporary approaches to Leadership, and Neo-Charismatic Theories. After the theory of Traits, behavioral leadership theories tried to explain leadership behavior and the relationship between group members.

In behavioral leadership theories, it becomes important what the leader does and how $\mathrm{s} / \mathrm{he}$ behaves. Leadership is influenced by behavior. Likewise, the behavior of the members following the leader also affects the behavior of the 
leader. The Michigan Studies, Iowa Studies, the Ohio State Studies, McGregor's Theory X and Theory Y, Likerts System 4 Approach, and Blake and Mouton's Managerial Grid are the main theories of behavioral theories.

The research of Michigan University aimed to find differences in behavior between effective and inefficient leaders. Leadership behavior has been determined in two ways; job-centered style and employee-centered style. In this context, directive leaders exhibit an attitude towards work rather than the expectations and needs of their employees/followers (Katz et al., 1950). McGregor was the first person to apply his findings in behavior sciences to leadership and business world, and his Theory $\mathrm{X}$ and Theory $\mathrm{Y}$ are one of the studies that form the basis of directive leadership and focus on the leader's behavior. In theory X, the results are the focus of leadership and are emphasized the authoritarian leadership style, and it is more work-centered than people-centered. Y theory, on the other hand, is a human-centered approach in which the individuals are valued and appreciated (Dartey-Baah, 2009). The most important factor that determines the behavior of managers is the assumptions about behavior (McGregor, 1960). In 1961, Likert stylized the Michigan's study results to demonstrate production-centered and employee- centered behaviors, thus emphasizing similarity with the results of Ohio State Studies (Liu et al., 2003). In the Ohio State Studies, leader behaviors were examined in two independent dimensions as initiating structure and consideration (Fleishman, 1953; Liu et al., 2003).

In this theory, to define behaviors, we encounter concepts such as democratic, autocratic and liberal leadership with the most well-known expressions. Therefore, the behavior of the leader is very important in terms of influencing members/followers. Gordon (1991) categorized behaviors of a leader as autocratic, informative, counselor and participant. Saruhan and Yildiz (2009) also defined the leader as the person who is influential in determining or changing the aims and behaviors of the group.

Behaviors of individuals who guide a group are very important. According to Halpin (1956), "the leadership behavior characterized by a high Initiation Structure and a high Consideration represents the ideal of a democratic leadership" that everyone is looking for. Baysal and Tekarslan (1996) stated that leader-group interaction in the organizations is mainly composed of listening, encouraging, clarifying thoughts and providing social-emotional support, and focusing on the behavior of the leader rather than on the attitudes of the leader and that these behaviors were perceived by the group members. According to Öz (2009), the leader behaviors performed according to theories of the transformational, goal-setting and leader-member-exchange are the leader behaviors that are most related to organizational citizenship behavior.

Rodriguez (2013) states that LBDQ has been used for more than 50 years and is still the most widely used scale in determining leadership behavior. In this study, LBDQ was also used. Using this questionnaire, some of the sports research conducted in Turkey are as follows.

The questionnaire was applied to the physical education (PE) teachers and school administrators by Can (2002), to the students of high school of the physical education and sports by Durukan (2003), Atar and Özbek (2009), and to the students of PE and sports management students by Kurudirek (2011). Atar and Özbek (2009) conducted factor analysis and the questionnaire was found to be two-factor as in the original questionnaire. In the study, the first factor consisted of 7 items $(1,2,3,4,5,6$ and 7) and the second factor consisted of 12 items $(8,9,10,11,12,13,14,15,16,17,18$ and 19). The dimensions of the questionnaire, as in the original scale, were named as the "initiating structure" and the second dimension as the "consideration".

In the light of all this information, in this research, the importance of leadership training has been emphasized. For that reason, in this study, it was aimed to determine the leadership training and leadership behaviors of university students who received Sports Management (SM) training on the basis of behavioral theories related to leadership.

For this purpose, five hypotheses were created:

Hypothesis 1. The leadership course of SM students was compulsory.

Hypothesis 2. There was a significant difference between gender and sub-dimension scores of the questionnaire of SM students.

Hypothesis 3. There was a significant difference between age groups and sub-dimension scores of the questionnaire of SM students.

Hypothesis 4. There was a significant difference between the status of doing sports as an athlete and sub-dimension scores of the questionnaire of SM students.

Hypothesis 5. There was a significant difference between the status of volunteering in sports events and sub-dimension scores of the questionnaire of SM students. 


\section{Method}

\subsection{Participants}

The sample of this study composed of 148 Sports Management students who were 112 males (75.7\%), 36 females $(24.3 \%)$. Considering the age groups of the students; 52 students $(35.1 \%)$ were in "20 years and under", 68 students $(46 \%)$ were in " $21-25$ years", 28 students $(18.9 \%)$ were in "26 years and older". While 56 students $(37.8 \%)$ stated that they did sports as an athlete, 92 students $(62.2 \%)$ stated that they did not do sports as an athlete. One hundred and six students (71.6\%) reported that they were volunteered in sports events and 42 students (28.4\%) were not.

\subsection{Procedure}

Data were collected in the fall term of 2018. The students filled out the questionnaire before the lessons, and it was administered by the researcher. The questionnaire was completed on average 10 minutes.

\subsection{Measures}

In this study, the Personal Information Form (PIF) and the Turkish version of Leader Behavior Description Questionnaire (LBDQ) were used as a data collection tool. PIF was created by the researcher in order to learn the characteristics of the students such as gender, age groups, the status of doing sports as an athlete and the status of volunteering in sports events. LBDQ was first developed by Hemphill and Coons (Şentürk ve Sağnak, 2012), and later, Halpin and Winer (1957) determined that the scale was dimensions of "initiating structure" and “consideration" (Stogdill, 1963). It was adapted into Turkish by Önal in 1979 (Atar \& Özbek, 2009; Durukan et al., 2006; Şentürk \& Sağnak, 2012), and revised as data collection tool by Atar and Özbek (2009). The Turkish version of questionnaire also consists of 19 items and two dimensions, as in the original questionnaire. The item grades of the 5-point Likert-type scale and their score ranges are as follows: 1-Never (1.00-1.79), 2-Seldom (1.80-2.59), 3-Occasionally (2.60-3.39), 4-Often (3.40-4.19), 5-Always (4.20-5.00).

\subsection{Analyses}

In this study, the SPSS package program was used for statistical analysis. T-test, ANOVA and Pearson's correlation test were used for the data analysis. The significance level for hypothesis was determined to be .05 . As a result of the reliability analysis, the Cronbach's alpha value was found to be .74 .

\section{Results}

The findings of the education program examined are as follows.

Table 1. Number of elective courses of SM students

\begin{tabular}{lllll}
\hline & Groups of elective courses & Elective Course (n) & Required for Graduation $(\mathrm{n})$ & Leadership Courses \\
\hline 1 & Off-field elective fall & 7 & 2 & \\
2 & Elective fall & 11 & 4 & -Leadership and sports \\
3 & Off-field elective spring & 7 & 2 & \\
4 & Elective spring & 10 & 4 & -Group dynamics and leadership \\
& & & 12 & -Educational leadership \\
& Total & 35 & & 3 \\
\hline
\end{tabular}

None of the leadership courses in the curriculum have been compulsory. It was found that there were 35 elective courses in the curriculum for Sports Management students. Three out of 35 elective courses were related to leadership courses.

The results of the data obtained from the students participating in the research were given in the tables below.

Table 2. Leadership behavior scores taken from LBDQ

\begin{tabular}{llllll}
\hline Dimensions & $\mathrm{n}$ & Min. & Max. & $\bar{x}$ & ss \\
\hline Initiating structure & 148 & 1.424 & 5.00 & 4.142 & 0.502 \\
Consideration & 148 & 2.578 & 5.00 & 3.760 & 0.461 \\
\hline
\end{tabular}

The mean score of SM students was found to be 4.142 in the dimension of initiating structure, and 3.760 in the dimension of consideration. 
Table 3. T-test results of the sub-dimensions of LBDQ according to gender

\begin{tabular}{llllllll}
\hline Dimensions & Gender & $\mathrm{n}$ & $\bar{x}$ & $\mathrm{ss}$ & $\mathrm{sd}$ & $\mathrm{t}$ & $\mathrm{p}$ \\
\hline Initiating structure & Male & 112 & 4.209 & 0.535 & 146 & 2.031 & $0.042^{*}$ \\
& Female & 36 & 4.048 & 0.447 & & & \\
Consideration & Male & 112 & 3.764 & 0.502 & 146 & 0.218 & 0.824 \\
& Female & 36 & 3.750 & 0.390 & & & \\
\hline
\end{tabular}

Note. $\mathrm{p}<.05$.

According to the results of the analysis, there was a significant difference between male and female students for initiating the structure dimension scores of LBDQ $\left[\mathrm{t}_{(146)}=2.031, \mathrm{p}<.05\right]$.

Table 4. ANOVA results of the sub-dimensions of LBDQ according to age groups

\begin{tabular}{lllllll}
\hline Dimensions & Age Groups & $\mathrm{n}$ & $\bar{x}$ & $\mathrm{~S}$ & $\mathrm{~F}$ & $\mathrm{p}$ \\
\hline Initiating structure & 20 years old and younger & 52 & 4.095 & 0.531 & & \\
& 21-25 years old & 68 & 4.235 & 0.355 & 2.086 & 0.103 \\
& 26 years old and older & 28 & 4.318 & 0.651 & & \\
Consideration & 20 years old and younger & 52 & 3.694 & 0.388 & \multirow{2}{*}{$0.016^{*}$} \\
& 21-25 years old & 68 & 3.985 & 0.417 & 3.491 & \\
& 26 years old and older & 28 & 3.790 & 0.464 & & \\
\hline
\end{tabular}

Note. $\mathrm{p}<.05$.

Although there was no significant difference between the initiating structure dimension scores of LBDQ according to age groups of $\mathrm{SM}$ students $[\mathrm{F}(2-145)=2.086, \mathrm{p}>.05]$, there was a significant difference between the consideration dimension scores of LBDQ according to age groups of SM students $[\mathrm{F}(2-145)=3.491, \mathrm{p}<.05]$

Table 5. T-test results of the sub-dimensions of LBDQ according to the status of doing sports as an athlete

\begin{tabular}{llllllll}
\hline Dimensions & Sports status & $\mathrm{n}$ & $\bar{x}$ & $\mathrm{ss}$ & $\mathrm{sd}$ & $\mathrm{t}$ & $\mathrm{p}$ \\
\hline Initiating structure & Yes & 56 & 4.260 & 0.474 & 146 & 2.238 & $0.024^{*}$ \\
& No & 92 & 4.073 & 0.512 & & & \\
Consideration & Yes & 56 & 3.829 & 0.502 & 146 & 1.368 & 0.141 \\
& No & 92 & 3.718 & 0.431 & & & \\
\hline
\end{tabular}

Note. $\mathrm{p}<.05$.

There was a significant difference between the initiating structure dimension scores of LBDQ according to the status of doing sports as an athlete of SM students $\left[\mathrm{t}_{(146)}=2.238, \mathrm{p}<.05\right]$.

Table 6. T-test results of the sub-dimensions of LBDQ according to the status of volunteering in sports events

\begin{tabular}{llllllll}
\hline Dimensions & Volunteering status & $\mathrm{n}$ & $\bar{x}$ & $\mathrm{ss}$ & $\mathrm{sd}$ & $\mathrm{t}$ & $\mathrm{p}$ \\
\hline Initiating structure & Yes & 106 & 4.250 & 0.501 & 146 & 4.772 & $0.000^{*}$ \\
& No & 42 & 3.838 & 0.382 & & & \\
Consideration & Yes & 106 & 3.840 & 0.473 & 146 & 4.309 & $0.000^{*}$ \\
& No & 42 & 3.538 & 0.342 & & & \\
\hline
\end{tabular}

Note. $\mathrm{p}<.05$.

According to the results of the analysis, in both dimensions, there was a significant difference between the status of volunteering in sports events of students and LBDQ scores.

Table 7. Correlation between students' leadership behavior

\begin{tabular}{lll}
\hline Describe Behavior & & Consideration \\
\hline Initiating structure & $\mathrm{r}$ & .469 \\
& $\mathrm{p}$ & .000 \\
& $\mathrm{n}$ & 148 \\
\hline
\end{tabular}


There was a linear and significant correlation between the scores of initiating structure and consideration $(\mathrm{r}=.469$, $\mathrm{p}<.05)$.

\section{Discussion and Conclusion}

When the Sports Management students' curriculum was examined in 2018, it was found that there were 35 elective courses, and only 3 of them were interested in leadership. In other words, the leadership courses were all elective courses. In addition, all of the elective leadership courses were theoretical. Students could choose one of these courses for a semester. As the leadership courses were elective, considering the other alternative courses, a student could graduate without choosing a leadership course. Considering the importance of leadership in areas related to management, it is thought that graduation without leadership training will be a deficiency. Therefore, the importance of leadership education was tried to be emphasized in this study.

The mean score of SM students was found to be 4.142 in the dimension of initiating structure, and 3.760 in the dimension of consideration. This result showed that the students' leadership behaviors were above the mean score. The level of the students' dimension of consideration was found to be higher than the dimension of initiating structure.

According to the results of the analysis, there was a significant difference between male and female students for the dimension of initiating structure scores of LBDQ. No significant difference was found in the other dimensions. In a similar way, in a study that examined leadership behavior (understanding dimension) of high school students participating in sportive recreation activities, a significant difference was found in gender variable (Yllmaz et al., 2015). These results support the same results in the dimension of consideration with the studies of Durukan et al. (2006), Atar and Özbek (2009) and Yalız Solmaz and Aydın (2015). But, some of the results obtained for this research were found to be different from previous studies. In a study conducted by Durukan et al. (2006) on gender, no significant difference was found between the physical education and sports college students' leadership behavior, except for the 1st and 6th items. In another study, Durukan et al. (2007) examined the students participating in inter-university competitions and found a significant difference between the gender and items (20, $22,24,25$, and 30) of the dimension of consideration, and they found no significant difference in other items. Yalız Solmaz and Aydın (2015) found no significant difference between gender of physical education and sports teacher candidates and dimensions of initiating structure and consideration.

There was no significant difference between initiating structure dimension scores of LBDQ according to age groups of SM students. But there was a significant difference between consideration dimension scores of LBDQ. In the study conducted by Yalız Solmaz and Aydın (2015), no significant difference was found between age and leadership behaviors sub-dimensions. It supports the study in the dimension of initiating structure this research.

There was a significant difference between initiating structure dimension scores of LBDQ according to the status of doing sports as an athlete. According to the results obtained in the study, the leadership behaviors of SM students who doing sports as an athlete revealed that they achieved higher scores in the dimension of initiating structure. In other words, it can be said that students who perform sports have better leadership behaviors than students who do not.

According to the results of the analysis, in both dimensions, there was a significant difference between the status of volunteering in sports events of students and LBDQ scores. In other words, the leadership behaviors of the students who volunteered in sports events were found to be higher in both sub-dimensions than in non-volunteer sports events. According to this result, it can be said that students who participate in sports events develop leadership behaviors.

When Table 7 is examined, there was a linear and significant correlation between the scores of initiating structure and consideration. In this case, it can be said that any increase in score type will increase the other score type. In other words, as the consideration feature increases, the initiating structure feature increases.

It can be said that the managers who take part in all kinds of enterprises, institutions or units that manage the human resources take their formal training at universities. Therefore, the training carried out in the relevant units of universities are of great importance in the training of the managers with leadership characteristics.

Even though virtual environments have increased with the advancement of technology, the importance of behavior among people still continues to gain importance. Training is the best tool for the permanence of behaviors. Therefore, training should be specific to the area concerned. In this context, a successful manager should have leadership characteristics. Considering the need to have leadership characteristics to be a successful manager, this study has tried to emphasize that leadership training should be given in the institutions or organizations that train in management and management. 
The results of the study revealed that the students were at a level above average scores in terms of initiating structure and consideration in showing leadership behaviors. When students graduate, they are thought to be successful managers and leaders by combining these behaviors with practice in business life.

\section{References}

Atar, E., \& Özbek, O. (2009). Beden eğitimi ve spor yüksekokulu öğrencilerinin liderlik davranışları. Spormetre Beden Eğitimi ve Spor Bilimleri Dergisi, 7(2), 51-59. https://doi.org/10.1501/Sporm_0000000150

Bayrak, S. (1997, Haziran). Değişen liderlik anlayışı ve Türkiye gerçeği. 21. Yüzyıl Liderlik Sempozyumunda sunulan bildiri, Cilt 1, 355-358. Istanbul: DHO Matbaası.

Baysal, A., \& Tekarslan, E. (1996). İşletmeler için davranış bilimleri (2. Baskı). İstanbul: Avcıol Basım Yayın.

Bozyigit, E. (2017). Sports management education in Turkish universities, analysis of undergraduate programs. Journal of Sports Science, 5(6), 345-348. https://doi.org/10.17265/2332-7839/2017.06.007

Can, S. (2002). Resmi ve özel okullardaki okul yöneticileri ve beden eğitimi öğretmenlerinin liderlik davranışı yönünden karşılaştırılması. Yayınlanmış Doktora Tezi, Atatürk Üniversitesi, Sosyal Bilimler Enstitüsü, Erzurum.

Çelik, V. (2005). Liderlik, eğitim ve okul yöneticiliği el kitabı. Ankara: Pegem Akademi Yayıncılık.

Dartey-Baah, K. (2009). Douglas McGregor's theoretical models: Their application in assessing leadership styles. Academic Leadership, 7(4).

Doğan, S. (2007). Vizyona dayalı liderlik (2. Baskı). İstanbul: Kare Yayınları.

Durukan, E. (2003). Selçuk Üniversitesi beden eğitimi ve spor yüksekokulu I. ve IV. sinıf öğrencilerinin liderlik davranışlarının karşıllaştırılması. Yayımlanmamış Yüksek Lisans Tezi, Selçuk Üniversitesi Sağlık Bilimleri Enstitüsü, Antrenörlük Eğitimi Anabilim Dalı, Konya.

Durukan, E., Can, S., Göktaş, Z., \& Arıkan, A. N. (2006). Selçuk Üniversitesi beden eğitimi ve spor yüksekokulu öğrencilerinin cinsiyete bağlı olarak liderlik davranışı (yapıyı kurma boyutu) yönünden karşılaştırılması. Gazi Üniversitesi Kırş̧ehir Eğitim Fakültesi, 6(1), 25-32.

Durukan, E., Can, S., Arıkan, A. N., \& Göktaş, Z. (2006). Selçuk Üniversitesi beden eğitimi ve spor yüksekokulu öğrencilerinin yapıyı kurma boyutunda liderlik davranışlarının sınıf düzeylerine göre karşslaştırılması. Ballkesir Üniversitesi Sosyal Bilimler Enstitüsü Dergisi, 9(15), 01-19.

Durukan, E., Can, S., \& Gök, A. (2007). Bir rekreasyon faaliyeti olarak - üniversitelerarası müsabakalara katılan sporcu öğrencilerin liderlik davranışlarının (anlayış gösterme boyutunda) karşılaştırılması. Spor Yönetimi ve Bilgi Teknolojileri Dergisi, 2(1), 23-30.

Eren, E. (2010). Örgütsel davranış ve yönetim psikolojisi (12. Baskı). İstanbul: Beta Basım Yayım Dağıtım A.Ş.

Fleishman, E. A. (1953). The description of supervisory behavior. Personnel Psychology, 37, 1-6.

FOE. (2019). Sports Management Program. The faculty of open education, Anadolu University. Retrieved from http://abp.anadolu.edu.tr/en/program/dersler/1640/13

FOE-SM. (2019). Program objective. Sports Management Program, The faculty of open education, Anadolu University.

Retrieved

from https://www.anadolu.edu.tr/en/open-education/programs-in-turkey/associate-degree-programs-in-the-facult y-of-open-education/sports-management

Gordon, J. R. (1991). A diagnostic approach to organizational behavior (3rd Edition). Boston.

Halpin, A. W. (1956). The behavior of leaders. Educational Leadership, 172-186. Retrieved from: https://pdfs.semanticscholar.org/d847/e03e8f2bb9d7e93864aee1615d654a5abb1c.pdf

Halpin, A. W., \& Winer, B. J. (1957). A factorial study of leader behavior descriptions. In: Leader Behavior: Its description and measurement. In R. M. Stogdill \& A. E. Coons (Eds.), Columbus: The Ohio State University, Bureau of Business Research, Monograph No. 88.

Katz, D., Maccoby, N., \& Morse, N. (1950). Productivity, supervision and morale in office situation. Ann Arbor, MI: Institute of Social Research.

Kurudirek, M. A. (2011). Spor yöneticiliği ile beden eğitimi ve spor öğretmenliği bölümü ögrencilerinin eğitim seviyelerinin liderlik düzeylerine etkisi. Yayımlanmamış Yüksek Lisans Tezi, Atatürk Üniversitesi, Sağlık Bilimleri Enstitüsü, Erzurum. 
Liu, A., Fellows, R., \& Fang, Z. (2003). The power paradigm of project leadership. Construction Management and Economics, 21(8), 819-829, https://doi.org/10.1080/0144619032000056199

McGregor, D. (1960). The human side of enterprise. New York: McGraw-Hill.

Nanjundeswaraswamy, T. S., \& Swamy, D. R. (2014). Leadership styles. Advanced in Management, 7(2), 57-62.

Oxford Dictionaries. (2019). Definition of behavior. Oxford Dictionaries. Retrieved from https://en.oxforddictionaries.com/definition/behaviour

Öz, E. (2009). Örgütsel vatandaşlık davranışı. In K. Aşkın, Y. Gözde \& Y. Senay (Eds.), Çalışma yaşamında davranış: Güncel yaklaşımlar (1. Basım). Kocaeli: Umuttepe Yayınları.

Öztürk, F. (1998). Toplumsal boyutlartyla spor. Ankara: Bağırgan Yayımevi.

Parlak, B. (2016). Yönetim bilimi ve çağdaş yönetim teknikleri (3. Baskı). İstanbul: Beta Basım Yayım.

PAU-IPCC. (2019). Pamukkale University, Sports Management Department. Information package and course catalogue. $\quad$ Retrieved from https://ebs.pau.edu.tr/BilgiGoster/Program.aspx?lng=2\&dzy=3\&br=8273\&bl=8277\&pr=579\&dm=1\&ps=0

PAU-SA. (2019). Objective of Sport Administration. Pamukkale University, Sports Management Department. Retrieved from https://ebs.pau.edu.tr/BilgiGoster/Program.aspx?lng=2\&dzy=3\&br=8273\&bl=8277\&pr=579\&dm=1\&ps=0

Rodriguez, R. (2013). Leadership behavior description ouestionnaire (LBDQ \& LBDQ-XII). In M. Bocarnea, R. Reynolds \& J. Baker (Eds.), Online Instruments, Data Collection, and Electronic Measurements: Organizational Advancements (pp. 97-117). Hershey, PA: IGI Global. https://doi.org/10.4018/978-1-4666-2172-5.ch006

Saruhan, S. C., \& Yıldız, M. L. (2009). Çağdaş yönetim bilimi. İstanbul: Beta Basım A.Ş.

Şentürk, C., \& Sağnak, M. (2012). İlköğretim okulu müdürlerinin liderlik davranışları ile okul iklimi arasındaki ilişki. Türk Ĕgitim Bilimleri Dergisi, 10(1), 29-47.

Şişman, M. (2002). Öğretim liderliği. Ankara: Pegem Akademi Yayıncılık.

Stogdill, R. M. (1963). Leader behavior description questionnaire-Form XII an experimental revision. Fisher College of Business the Ohio State University.

Tengilimoğlu, D. (2005). Kamu ve özel sektör örgütlerinde liderlik davranışı özelliklerinin belirlenmesine yönelik bir alan çalışması. Elektronik Sosyal Bilimler Dergisi, 4(14), 01-16.

Yalız, S. D., \& Aydın, G. (2015). Beden eğitimi ve spor öğretmen adaylarının liderlik özelliklerinin bazı değişkenlere göre incelenmesi. Uluslararası Sosyal Araştırmalar Dergisi, 8(41), 1077-1084.

Yılmaz, T., Öztür, H., \& Alıncak, F. (2015). Sportif rekreasyon faaliyetlerine katılan lise öğrencilerinin liderlik davranışının (anlayış gösterme boyutu) İncelenmesi. Niğde Üniversitesi Beden Eğitimi ve Spor Bilimleri Dergisi, 9 (Özel Sayı), 50-57.

\section{Copyrights}

Copyright for this article is retained by the author, with first publication rights granted to the journal.

This is an open-access article distributed under the terms and conditions of the Creative Commons Attribution license (http://creativecommons.org/licenses/by/4.0/). 